\title{
Water User's Conflicts in Irrigation Schemes in Tanzania
}

\author{
Saida Selemani Fundi \\ Lecturer $(\mathrm{PhD})$, Mzumbe University, Tanzania \\ School of Public Administration and Management \\ E-mail: sfundi@mzumbe.ac.tz
}

Stella Malangalila Kinemo

Senior Lecturer (PhD), Mzumbe University, Tanzania

School of Public Administration and Management

E-mail: smkinemo@mzumbe.ac.tz

Received: Oct. 11, 2018 Accepted: Nov. 13, 2018 Online published: Nov. 26, 2018

doi:10.5296/jpag.v8i4.13965 URL: https://doi.org/10.5296/jpag.v8i4.13965

\begin{abstract}
The aim of this study was to examine types of water users' conflicts and factors contributing to their occurrence in water allocation processes in small scale irrigation schemes in Tanzania. The study was conducted at Mkindo Irrigation Scheme and employed the Exploratory Sequential Mixed Approach, whereby both the qualitative and quantitative techniques were used. Specifically, the qualitative techniques were employed to explore the nature of water users' conflicts while the quantitative approaches were used as supplementing techniques in analysis of incidences, prevalence and determinants of such conflicts in the scheme.

The data collection methods were in-depth interviews, documentary reviews and focus group discussions for the qualitative data and questionnaire for quantitative data. Qualitative data were analysed using qualitative content analysis and explanation building techniques. The quantitative data were analysed using descriptive and inferential statistics.

Findings revealed existence of inter-micro micro and intra micro-micro water users' conflicts in the selected irrigation scheme. The study also identified the factors determining the water user's conflicts in the selected scheme exacerbated mostly by absence of effective water conveyance infrastructures. To enhance water allocation processes at Mkindo Irrigation
\end{abstract}


Scheme, the study recommends strengthening of the infrastructures for conveying water from sources to the farms.

Keywords: conflict, water user conflict, irrigation scheme

\section{Introduction}

The water sector attracts multiple institutions due to water's centrality to the wellbeing of mankind. In Tanzania importance of water is attributable to its role in the development of the country's agricultural sector. Agriculture is the mainstay of Tanzania's economy as it contributes about $23 \%$ of the nation's GDP, nearly $30 \%$ of the country's exports and employs nearly $66.9 \%$ of the country population (URT, 2016). Due to its importance to the national income and people's livelihoods, the government of Tanzania (GOT) has made agriculture one of the top priority activities in national economic strategies. Cognizant of the unreliability of rainfall in the country, the GOT decided to embark on improving the small scale irrigation schemes so as to enhance agro-production. Improvement of small scale irrigation schemes is considered to be an important step in realizing food security and poverty alleviation targets articulated in MKUKUTA. Small scale irrigation schemes are perceived as appropriate engines for development particularly rural development due to their impacts on improving the livelihoods of the rural population. Several examples exist showing how small scale irrigation schemes have been essential for livelihoods enhancement in different rural areas in Tanzania (Mkavidanda and Kaswamila, 2001; Keraita et al., 2012; Mdee et al., 2014).

GOT's policies on irrigation farming have stimulated engagement of the small scale farmers in irrigation activities and consequently resulted to changes in water use patterns and behaviors in that respect (URT, 2002b). Generally, the policies and demographic trends have resulted to evolution of multiple institutions in small scale irrigation schemes making management of the water resource in such schemes challenging (URT, 2002b; URT, 2010; IUCN, 2010). One of the challenges is how to establish collective action in the management of water allocation processes and control of users' conflicts in the context where multiple institutions interact. Basing on this background this article examines water user conflicts at Mkindo Irrigation Scheme (MIS) in Mvomero District, Tanzania.

\section{Literature Review}

\subsection{Meaning and Nature of Conflicts in Water Use}

As it has been indicated in the literature (Mbeyale, 2009; Bijani and Hayati, 2015; Maganga et al., 2004), conflicts are common features to most water allocation arenas. Upretti (2004b) defines conflict "as a clash of interests, complaints in public, protests, and filing cases with the local administration and courts" (Upretti, 2004b) cited in (Nkonya et al., 2009: 3). In this study, conflicts are regarded as disagreements over access or use of the resource that can lead to violent or non-violent encounters among or between individuals or groups. There are different levels at which conflicts can be manifested. According to Sanginga et al. (2007) and Edossa et al. (2007) in Nkonya et al. (2009) resource use conflicts can be found at community, inter-community, or supra community levels. With respect to the land or water resources, users' conflicts can be found also at the farm level involving individual farmers or 
an individual farmer with a group of other farmers or between groups of farmers (Nkonya et al., 2009). According to Warner (2000) cited in Mbeyale (2009), conflicts can be classified as intra-micro micro, inter micro- micro and inter micro-macro. The intra micro-micro conflicts are those conflicts happening within a resource utilisation context involving for instance users claiming access to resource basing on different resource regimes for example, between private or government and communal rights holders. The inter micro-micro conflicts take place between the resource owners and users or indigenous and non-indigenous users and are induced mostly by clash of interests between groups having cultural differences. Other conflicts in this category are those arising out of wealth disparities, non-cooperative behavior of the resource use groups and exclusion from decision making systems. The inter-micro macro are those conflicts happening between community groups and outside project sponsors or managers and those caused by political influence.

\subsection{Water Allocation Institutions in MIS}

As it has been pointed out in Le Quesne et al. (2007) water allocation refers to "the process whereby an available water resource is distributed to legitimate claimants and the resulting water rights are granted, transferred, reviewed, and adapted". It involves distribution of water from the source to the points of use. Water allocation is an arena in which actors of different identities, capabilities and interests affect decisions and processes on who should get what, how and when through utilisation of multiple institutions. To enhance management and distribution of the water to the farmers, the scheme has devised some local institutions. Some of these institutions reflect mostly the formal guidelines insisted in National Water Policy (NAWAPO) of 2002 and Water Resource Management Act (WRMA) of 2009 and some are more informal reflecting mostly the needs of the users. These institutions are calendar and constitution. The calendar is used as an instrument used by the farmers in the MFIS to guide the farming and water distribution activities.

As a move to enhance management of the water resources in their scheme, the farmers in MFIS have established a written constitution in which various functions of the leaders, rules governing water allocations and penalties for the shirkers have been clearly articulated. Such rules and penalties guide the leaders in various committees in their decisions on various issues including the decisions on how water should be distributed among the members. The rules are concerned with the scheme's farming calendar, canals cleanliness, timely payment of the contributions and water bills, farmers' participation in construction and O\&M activities, and the seed that the farmers have to sow in their farms.

\subsection{Empirical Studies on Water Users' Conflicts}

Although formal water allocation processes have been insisted in various national policies and laws in Tanzania, they are not necessarily effective in management of users' conflicts. Different studies have indicated prevalence of water users' conflicts in water allocation processes in Tanzania and beyond resulting from formalisation of resource management. For instance, the urbanities in Tanzania take advantage of the Water Act which gives priority to domestic water to claim use of water which was formally used for irrigation by the small scale farmers in rural areas (Komakech et al. (2012). This tendency has intensified scarcity 
and competitions in such areas and resulted to conflicts among the users as the study by Komakech et al. (2012) indicated. In addition, the tendency to ignore prior infrastructural investments during establishment of the formal allocation institutions and mechanisms is a contributing factor to persistence of water users' conflicts in local areas. The study by Komakech et al. (2012) has revealed how rejection of the prior water rights has led to resentments and finally conflicts between the big and small water users. In another study conducted in Kenya, Mutinga et al. (2010) showed how excessive exploitation of water for irrigation use from Ewaso Ng'iro River and poor coordination of water resource management activities contribute to scarcity and consequently emergence of water users' conflicts. Although scarcity has been mentioned as a factor contributing to competitive access and conflicts among the users, some studies have found more cooperative than competition during scarcity. For example, in their study, Witsenburg and Adano (2003) cited in Meinzen-Dick and Nkonya (2007) found reduction in water use conflicts during drought because the farmers faced a new enemy-hunger which they had to fight collectively. Generally, various studies have indicated that, most of the water users' conflicts in irrigation schemes result from attempts to centrally formalise the water users' rights rather than how water is used by the people (Van Koppen et al., 2004; Meinzen-Dick and Nkonya, 2007; Komakech et al., 2011; Komakech et al., 2012). As the study by Weiss (2004) cited in Meinzen-Dick and Nkonya (2007) has shown, local people have been capable of devising collective action towards water even in the situation of heterogeneous ethnic values. Such studies however contravene the argument by van Koppen et al. (2007) which indicates that collective action is difficult to achieve in communities with heterogeneous ethnic groups.

Apart from conflicts incidences, empirical studies also indicate approaches used for their resolutions. In most cases the findings from different studies have indicated divergence between the government policies on conflicts resolutions and the actual practice in the local areas. While the national water policies have the focus only on the formal structures and procedures for reporting and resolving the conflicts, the experiences show that conflicts are also managed through informal institutions and mechanisms. The studies by Maganga et al., (2004), Nkonya et al., (2009); Kramm and Wirkus (2010), Komakech et al., (2011) show that, most of the water users in local areas prefer to use informal conflict resolution institutions and mechanisms such as face to face discussions than registering the cases to the formal courts of law. It is only in the situations that such institutions and mechanisms have faced challenge that most water users will send the matter to the courts.

Drawing from the findings of different studies, formal-informal institutional relations and their results in water use conflicts are dynamic. While in some circumstances they act as useful building blocks for water resource management and in particular water resource allocation, in other situations they have been a stumbling block for water allocation and catalysts for conflicts.

\section{Methodology}

\subsection{Area of the Study}

This study was conducted at Mkindo Irrigation Scheme (MIS) of Wami-Ruvu Basin (WRB) 
in the Morogoro region in Tanzania. The Wami-Ruvu Basin is one of the nine water basins in Tanzania that have been established under the Water Utilisation (Control and Regulation) Act No. 42 of 1974. MIS was purposively selected from WRB due to presence of completely lined main irrigation canal, presence of heterogeneous ethnic groups with different economic interests and resource endowments and presence of Water User Association (WUA) in the area where it operates.

\subsection{Sample Size and Sampling Techniques}

The study population comprised all potential users of the water resource from the selected scheme, and the local leaders from the scheme and village governments, the officials from Mvomero District Council, the Council in which the Mkindo Irrigation Scheme is located and the Wami-Ruvu Basin staff. The total sample of 125 respondents was used in the study, of which 100 were respondents for house hold survey, 15 participants for Key Informants Interviews and 5 participants for FGDs. Purposive sampling was used in selecting the Mkindo Irrigation Scheme. The scheme was selected purposively due to presence of water use conflicts. Purposive sampling was also used in selecting the key informants who comprised the officials in the Wami-Ruvu Basin Water Office (WRBWO), Mvomero District Council (MVDC), and village chairpersons from Mkindo and Kambala villages.

Those selected from the WRBWO were the Basin Water Officer, an accountant, an environmental engineer, hydrologist, Community Development and Public Relations Officer (CDPRO) as well as the human resource officer. From the district councils the key informants selected were the District Agricultural, Irrigation and Cooperative Officer (DAICO) and the Irrigation Officer. The officials were selected because they had important knowledge, skills, and information about management of irrigation infrastructures, and control of the water resource and the resulting conflicts among the irrigators in small scale irrigation schemes around the area. At the ward and village levels, the selected key informants were one councillor and one Village Chairperson for Mkindo and Kambala villages. These were included in the study due to their roles as overseers of water management activities and conflicts resolution processes in the schemes and villages in general. The other key informants in this study were one chairperson and one secretary from Mkindo Farmers Irrigation Scheme (MFIS) and non-member irrigators' association in MIS, known as the Umoja wa Umwagiliaji Mgongola (UUMGO). These were selected purposively because the overall management of the scheme rest in their hands. Snowball sampling was used in identification and selection of the participants for the FGDs from among the members and non-member irrigators. Stratified random sampling technique was used to draw the study sample for the household survey. Before the sample was selected the irrigators were divided into two strata of women and men by the aid of the irrigators' register from the scheme.

\subsection{Data Collection and Analysis}

The in-depth interviews were conducted to the key informants and focused on getting data on the implementation of the National Water Policy, Water Resource Management Act and the basin's IWRM\&D Plan, management of the water resources allocations and users' conflicts. The interviews conducted with the Ward Councillors and village chairpersons focused on 
management of the water users' conflicts in the scheme. Interviews with the MFIS, UUMGO, and Mkindo WUA chairpersons and secretaries intended to obtain information on the day to day management of the scheme and water users' conflicts. FGDs were conducted to achieve two major purposes, namely; to unveil understanding of water use conflicts and explore experiences of the water users in conflicts. Documentary review was also used as data collection method. The documents that were reviewed are the National Water Policy (NAWAPO) (2002), The Water Resource Management Act (2009), IWRM\&D Plan, and National Irrigation Policy (NIP) (2010). The closed ended questionnaire was used to collect the survey data related to incidences and frequencies of farmers' involvement in water users' conflicts and their perception about the factors influencing occurrence of such conflicts in the scheme. Two qualitative techniques, namely qualitative content analysis and explanation building were used to analyse qualitative data. Quantitative data were analysed using descriptive and inferential statistical analyses. The descriptive statistical analysis involved the use of percentages and frequencies to interpret the findings from questionnaire. For the inferential statistical analysis the Binary Logistic Regression Model was used because the dependent variable, Involvement in Conflicts (COIV) was dichotomous with the value of 1 if a farmer was involved in conflicts otherwise 0 . The logistic model used was in the form;

$$
\operatorname{Logit} P(x)=\alpha+\sum_{i=1}^{k} \beta_{i} x_{i}+\varepsilon_{i}
$$

Therefore the model was specified as follows:

$$
\begin{aligned}
& \text { COIV }=\alpha+\beta_{1} \text { HHlse }+\beta_{2} \text { HHAge }+\beta_{3} \text { HHlmrista }+\beta_{4} \text { HHled }+\beta_{5} \text { HHCuprim }+\beta_{6} \text { membership }+ \\
& \beta_{7} \text { Waterscty }+\beta_{8} \text { Excesve }+\beta_{9} \text { Encroach }+\beta_{10} \text { Violation }+\beta_{11} \text { Exclusion }+\beta_{12} \text { Migration }+\beta_{13} \text { Benefit }+ \\
& \beta_{14} \text { LawAware }+\beta_{15} \text { Invov }+\beta_{16} \text { FarEx }+\varepsilon
\end{aligned}
$$

\section{Findings and Discussion}

This part presents the results of the analysis of conflicts types, prevalence of water users' conflicts in allocation processes and the factors determining their occurrence.

\subsection{Types and Causes of Conflicts}

Various types of water use conflicts exist in Mkindo Irrigation scheme but they can broadly be categorised as inter-micro micro and intra micro-micro (Warner, 2000 in Mbeyale, 2009). Interviews with the farmers and village and scheme leaders have revealed three major types of conflicts in the MIS falling within such categories. These are conflicts between the members in Mkindo Farmer Irrigation Scheme (MFIS) group and non-member irrigators from Umoja wa Umwagiliaji Mgongola (UUMGO), conflicts between the irrigators in MFIS and UUMGO members in one hand and the Maasai pastoralists in the other and conflicts amongst the farmers inside MFIS and UUMGO groups. The first two types of conflicts fall within the category of inter micro-micro and the last one within the category of intra micromicro conflicts.

To ascertain existence of water users conflicts some official statistics showing reported cases 
for five years from 2011 to 2015 were sought from MFIS, Mkindo WUA and Mkindo village government offices. Such official records show that during this period approximately 70 conflicts have been reported to the MFIS, Mkindo WUA and village government leaders (see table 1). Among these, 45 are intra micro-micro conflicts involving the farmers in MFIS, 27 are inter micro-micro conflicts involving the MFIS members and non-members in Umoja wa Umwagiliaji Mgongola (UUMGO) and 8 conflicts are between farmers in MFIS group and the pastoralists.

Table 1. Number of Intra and Inter Micro-micro Conflicts in MFIS from 2011 to 2015

\begin{tabular}{|c|c|c|c|c|c|c|}
\hline \multirow{2}{*}{$\begin{array}{l}\text { Type of } \\
\text { Conflicts }\end{array}$} & \multicolumn{5}{|c|}{ Frequency annually } & \multirow[t]{2}{*}{ Total } \\
\hline & 2011 & 2012 & $3^{201}$ & $\begin{array}{l}201 \\
4 \\
\end{array}$ & $5^{201}$ & \\
\hline $\begin{array}{l}\text { Intra- micro micro } \\
\text { (among members) }\end{array}$ & 11 & 8 & 9 & 4 & 5 & 35 \\
\hline $\begin{array}{l}\text { Inter-micro micro } \\
\text { (with pastoralists) }\end{array}$ & 3 & 4 & 1 & 0 & 0 & 8 \\
\hline $\begin{array}{c}\text { Inter-micro micro } \\
\text { (with the } \\
\text { non-members) }\end{array}$ & 11 & 4 & 5 & 3 & 4 & 27 \\
\hline Total & 23 & 15 & 11 & 11 & 10 & 70 \\
\hline
\end{tabular}

Source: Mkindo Scheme and village government reports

Basing on Table 1, there are decreasing trends in the number of inter micro- micro conflicts between the farmers and pastoralists in this scheme. According to the chairmen for Mkindo WUA and MFIS such trends are attributed to the decrease in pastoralists encroachments contributed by deployment of the local militia group known as Mwano and strength of the irrigation infrastructures. It is not only the conflicts between MFIS and the pastoralists that are decreasing, but also between this group and the out of scheme irrigators in UUMGO. The decreasing trend in MFIS-UUMGO conflicts has been contributed by the recent decision by the MFIS leaders to sell the access rights of water to the UUMGO farmers. As a result of such agreement, the farmers in UUMGO now have rights to get the allocations just like their colleagues in MFIS as long as they pay the water user fees in each farming season.

Existence of water use conflicts in MIS has also been analysed basing on the number of intra micro-micro conflicts among the non-member irrigators in UUMGO and between these irrigators and the pastoralists (inter-micro micro conflicts) reported to leaders in UUMGO group and village government office (see Table 2). Basing on table 2, there are also some decreasing trends in inter-micro-micro conflicts between the UUMGO and Maasai pastoralists. Again, the farmers have attributed such trends to establishment of Mwano. 
Table 2. Number of Intra and Inter Micro-micro Conflicts in UUMGO from 2011 to 2015

\begin{tabular}{lcccccc}
\hline $\begin{array}{c}\text { Type } \\
\text { Conflicts }\end{array}$ & of & \multicolumn{3}{c}{ Frequency annually } & & Total \\
& & & & & & \\
& $\mathbf{2 0 1 1}$ & $\mathbf{2 0 1 2}$ & $\mathbf{2 0 1 3}$ & $\mathbf{2 0 1 4}$ & $\mathbf{2 0 1 5}$ & \\
& & & & & & \\
\hline Intra- micro micro & 15 & 10 & 12 & 9 & 11 & 57 \\
Inter-micro micro & 22 & 25 & 10 & 8 & 5 & 70 \\
\hline \multicolumn{1}{c}{ Total } & $\mathbf{3 7}$ & $\mathbf{3 5}$ & $\mathbf{2 2}$ & $\mathbf{1 7}$ & $\mathbf{1 6}$ & $\mathbf{1 2 7}$ \\
\hline
\end{tabular}

Source: Scheme and village government reports

Through the in-depth interviews with the village chairpersons for Mkindo village and Mkindo scheme and focus group discussions (FGDs) with the farmers in MFIS and UUMGO groups, the study has identified different causes of water users' conflicts in Mkindo Irrigation Scheme. Initially, existence of multiple institutions was presumed to be the major factor contributing to emergence of water users' conflicts in this scheme. Through the interviews and FGDs influence of institutional multiplicity on water users' conflicts was observed. Specifically, heterogeneity in cultural values and economic interest between the farmers and pastoralists has prevented development of common rules and created the environment for frequent clashes between the two groups.

Although conflicts between the farmers and pastoralists are common to both, the scheme members and non-members, they are pronounced mostly in the later than the former. According to the farmers, conflicts with the pastoralists are severe in UUMGO due to behaviour of the pastoralists to feed and water their livestock through the farms. Presence of strong irrigation canal in phase I and II of the scheme where the members irrigate discourages the pastoralists from sending their cattle in the farms. This being the case, the farmer-pastoral conflicts incidences are few in these areas. In addition, the scheme and village government leaders have directed big efforts in ensuring that regular inspections are conducted to identify any encroachment in the intake area and around the scheme in general and provide strong punishment for those who are caught. Lack of strong canals and absence of inspection activities in the areas where the non-member irrigators from UUMGO irrigate has made it possible for the pastoralists to send their cattle inside the farms. This situation has contributed to frequent outbreak of the conflicts.

Poor infrastructures do not contribute to farmer-pastoral conflicts only but also conflicts between the members and non-member irrigators. Due to uncertain supplies caused by presence of poor infrastructures for conveying water from the source to the farms, the farmers in UUMGO have opted to use water from the MIS. In the course of using such water the irrigators in UUMGO have experienced frequent confrontations with their colleagues in the MFIS group who own and control the improved irrigation infrastructures. The conflicts exist because the members of UUMGO are dissatisfied with the water fees which are charged by the members of MFIS. Farmers in both schemes assume that such conflicts could have been avoided if the government fulfilled its promise to improve irrigation infrastructures in Mgongola scheme, where the plots for UUMGO members are found. 
Apart from inter-groups, poor infrastructures also cause intra micro-micro conflicts. These are conflicts among the members within Mkindo Farmer Irrigation Scheme (MFIS) and Umoja wa Umwagiliaji Mgongola (UUMGO). Umoja wa Umwagiliaji Mgongola (UUMGO) means Association of Irrigators in Mgongola area. In MFIS the conflicts are caused by lack of canals for draining water out of the farms. Due to existence of water lodge, the drain canals are very crucial in MFIS. While some farmers have constructed them, others have not. Interviews revealed that some farmers think that construction of the off-take canals reduce the size of their farms. Those who do not have the drain canals for taking water out of their farms normally take such water out through the adjacent farms. This behaviour fuels conflicts because sometimes the crops in the nearby farm do not want water, and thus, leaving the water to flow into it brings damage to the crops. In addition to that, sometimes the water that is left to flow into the nearby farm after being used for irrigation in another farm is polluted due to application of fertilisers and pesticides. The owner of the farms to which the polluted or excessive water has been left to flow normally reacts by quarrelling with the polluter.

The conflict between Mrs Kandy and Mr Njemi (not real names) illustrates the case for such kind of water users' conflicts. In this particular case, conflict has emerged because of the tendency by Mr Njemi to take water out of his farm through Mrs Kandy's farm. According to Mrs Kandy excessive water from Mr Njemi has been causing water lodging in her farm and due to water lodging she has failed to apply fertiliser in her farm.

"I have made several attempts to apply fertiliser but I failed due to water lodging in my farm. I have tried to ask Mr Njemi to stop leading water into my farm so that I could apply the fertiliser but he would not listen. I have reported the matter to the scheme leaders but they have taken no action. I am now intending to send this case to the village government or the court if necessary"

Intra-group conflicts are not found in MFIS only but also the Umoja wa Umwagiliaji Mgongola (UUMGO) group. Umoja wa Umwagiliaji Mgongola means association of Irrigators in Mgongola area. In this group the main cause according to the findings from the study is scarcity of water caused by use of poor conveyance infrastructures. Due to poor conveyance infrastructures, most of water is lost on the way causing scramble over access. Generally most farmers who were interviewed perceive poor infrastructures as the main source of conflicts in MIS.

\subsection{Prevalence of Conflicts}

After understanding of the water users conflicts in the perspectives of the few interviewed farmers the study had to understand prevalence of such conflicts and their contributing factors across the wider irrigators' population through household survey. Frequencies were to be computed to understand magnitude or prevalence of conflicts and Logistic Regression model was to be performed to determine the factors influencing farmers' involvement in water use conflicts. Findings have indicated prevalence of water users conflicts in this scheme despite availability of improved irrigation scheme.

Survey results show that users' conflicts are rampant in MIS despite reforms. Apart from the 
number of conflicts that have been reported for resolutions, prevalence of conflicts in this scheme has been measured basing on frequency of the farmers' involvement in different types of conflicts. Basing on survey results, only 30\% (15 out 50) of scheme members in Mkindo Farmers Irrigation Scheme (MFIS) group have reported to have experienced conflicts with the fellow members since they have started to engage into irrigation activities in MIS. This is smaller percentage compared to that of the non-member irrigators in UUMGO group. In this group $86 \%$ (43 out of 50) of the farmers have experienced conflicts with their fellow irrigators in the group in the course of sharing water for irrigation. The frequency of farmers' involvement in water users' conflicts for both groups is summarised in Table 3

Table 3. Frequency of Farmers Involvement in Intra micro-micro Conflicts in MIS

\begin{tabular}{l|l|l|l|l}
\hline \multirow{2}{*}{$\begin{array}{l}\text { Frequency } \\
\text { involvement }\end{array}$} & \multicolumn{2}{|c|}{ MFIS Members } & \multicolumn{2}{c}{ UUMGO Members } \\
\cline { 2 - 5 } & $\begin{array}{l}\text { No. of } \\
\text { respondents }\end{array}$ & Percentage & $\begin{array}{l}\text { No } \\
\text { respondents }\end{array}$ & $\begin{array}{l}\text { Percentag } \\
\text { e }\end{array}$ \\
\hline Never & 28 & 56 & 2 & 4 \\
\hline Sometimes & 10 & 20 & 5 & 10 \\
\hline Often & 7 & 14 & 9 & 18 \\
\hline Too often & 3 & 6 & 11 & 22 \\
\hline Always & 2 & 4 & 23 & 46 \\
\hline Total & $\mathbf{5 0}$ & $\mathbf{1 0 0}$ & $\mathbf{5 0}$ & $\mathbf{1 0 0}$ \\
\hline
\end{tabular}

Source: Household Survey (2015)

Apart from intra-group conflicts, the non-member irrigators in UUMGO also have high frequencies of involvement in conflicts with the Maasai pastoralists. The responses from the household survey indicate that 42 out of 50 farmers in this group equivalent to $84 \%$ said that they have been involved in water use conflicts with the Maasai pastoralists since they started to irrigate in the scheme due to encroachment behaviour. In MFIS group only 4 farmers out of $50(8 \%)$ admitted to have experienced conflicts with the pastoralists due to encroachment. Frequencies of farmers' involvement in water use conflicts with the pastoralists are summarised in table 4.

Table 4. Frequency of Farmers' Involvement in Conflicts with Pastoralists in MIS

\begin{tabular}{l|l|l|l|l}
\hline \multirow{2}{*}{$\begin{array}{l}\text { Frequency } \\
\text { involvement }\end{array}$} & \multicolumn{2}{|c|}{ MFIS Members } & \multicolumn{2}{c}{ UUMGO Members } \\
\cline { 2 - 5 } & $\begin{array}{l}\text { No. of } \\
\text { respondents }\end{array}$ & Percentage & $\begin{array}{l}\text { No } \\
\text { respondents }\end{array}$ & $\begin{array}{l}\text { Percentag } \\
\text { e }\end{array}$ \\
\hline Never & 27 & 54 & 2 & 4 \\
\hline Sometimes & 10 & 20 & 6 & 12 \\
\hline Often & 6 & 12 & 10 & 20 \\
\hline Too often & 5 & 10 & 12 & 24 \\
\hline Always & 2 & 4 & 20 & 40 \\
\hline Total & $\mathbf{5 0}$ & $\mathbf{1 0 0}$ & $\mathbf{5 0}$ & $\mathbf{1 0 0}$ \\
\hline
\end{tabular}

Source: Researcher's Household Survey (2015) 
In addition to inter group conflicts between the farmers and the pastoralists, prevalence of water use conflicts has been analysed basing on frequency at which the non-member irrigators in UUMGO are involved in conflicts with the scheme members in MFIS. The findings from the household survey indicate that majority of the farmers in UUMGO group (35 out of 50) equivalent to $70 \%$ have been involved in conflicts with the MFIS group in the course of using water from the scheme. Frequencies of conflicts between the UUMGO members and MFIS group are summarised in table 5.

Table 5. Frequencies at which the UUMGO Farmers are Involved in conflicts with MFIS group

\begin{tabular}{lll}
\hline Frequency of involvement & No. of respondents & Percentage \\
\hline Never & 2 & 4 \\
Sometimes & 7 & 14 \\
Often & 12 & 24 \\
Too often & 10 & 20 \\
Always & 19 & 38 \\
\hline Total & $\mathbf{5 0}$ & $\mathbf{1 0 0}$ \\
\hline
\end{tabular}

Source: Researcher's Household Survey (2014)

Generally, the household survey has shown that conflicts are still rampant in MIS despite formalisation of the water allocation processes through the water users' permits and tariffs and establishment of the formal water users groups. Although all farmers experience conflicts, their magnitudes are higher for the non-member irrigators due to utilisation of poor irrigation infrastructures than the farmers having membership to the scheme.

\subsection{Factors Influencing Occurrence of Conflicts}

After understanding the magnitude of conflicts, the study aimed to understand the factors influencing such conflicts across a wider population of the irrigators by using the logistic regression model and the results are as shown in table 6. Basin on this table, the factors determining water users' conflicts across the broader population of the farmers are farming experiences, water scarcity and benefits.

Table 6. Marginal effect on Factors Influencing Water Use Conflicts among Farmers in MIS

\begin{tabular}{lll}
\hline Variables & $\mathbf{d y} / \mathbf{d x}$ & $\mathbf{P}>\mathbf{z}$ \\
\hline Sex of the hhh & 0.0710432 & 0.286 \\
Age of hhh & 0.0055166 & 0.51 \\
Education level hhh & 0.0802924 & 0.944 \\
Farming experience & 0.0454771 & $0.000^{* *}$ \\
Water Scarcity & 0.0794936 & $0.007^{* *}$ \\
Encroachment & 0.1052754 & 0.13 \\
Exclusion & 0.1172116 & 0.502 \\
Benefits & 0.0952382 & $0.014^{*}$ \\
Laws awareness & 0.0912661 & 0.231 \\
Involvement & 0.0918645 & 0.766 \\
Scheme membership & 0.1209471 & 0.931 \\
\hline
\end{tabular}


$*$ and $* *$ are significance level at $5 \%$ and $1 \%$ respectively

\subsubsection{Farming Experience}

The results show that farming experience is positively correlated (0.045) with involvement in water users conflicts and statistically significant at $\mathrm{p}<0.01$. This implies that an increase in experience in irrigated farming increases the probability of farmers' involvement in water users' conflicts by $4.5 \%$. This relationship is contrary to the expected sign which hypothesized that when people stay together for long period of time it is easy to develop the norms of trust and reciprocity and avoid conflicts observed also by Ostrom (2000). Such norms normally help people to reach common agreements more easily in various decision making arenas and avoid disagreements that can develop to conflicts. Similarly the farmers with long experiences in irrigation were expected to have common understanding and trust on each other and exhibit non-conflictive behaviours than those who have recently joined the irrigation groups. The possible explanation for the above result is that perhaps the current competitions for the water have eroded the culture of togetherness and promoted more individualistic norms which fuel conflicts among the farmers than before. But with respect to farmer-pastoral conflicts the results were expected. Interviews found that all farmers regardless of their experiences react in a conflictive way whenever they find the animals drinking or eating from their farms. When it comes to the interactions between the farmers and pastoralists no possibilities of trust or mutual communication is normally found between the two groups. Generally, as the farmers continue with irrigation activities their chance of clashing with the pastoralists increases therefore the results showing positive association between the farmers' experiences and the water users' conflicts are not surprising in this case.

\subsubsection{Water Scarcity}

Table 6 indicates that water scarcity is also positively (0.079) related to farmers involvement in water conflict and is statistically significant at $\mathrm{p}<0.01$, implying that an increase in water scarcity, increases the probability of water users' conflicts among the community by $7.9 \%$. This association is logical and is as assumed by the study, because normally when the farmers do not have enough water to share conflicts prevail in allocation arenas as contended in Lecoutere, (2010) and Mbeyale (2009). In MIS acute scarcity of the water resource happens during the dry seasons and experienced by the out of scheme irrigators. These irrigators experience scarcity not because there is no enough water in the source but because they lack effective technology for transporting such water from the source to the farms. As for their colleagues irrigating inside the scheme such problem does not exist because in the areas where their plots are located, the main canal to convey water from the source to the farms has already been lined.

In addition to technology induced, in MIS there is also distributional and relational scarcity faced by the out of scheme irrigators (UUMGO group) arising from the existing power relations (Kramm and Wirkus, 2010) between them and their colleagues who have membership to the scheme. The study has found that access to water is controlled by the scheme members who use the advantages of possessing a water use permit and their upstream location against the out of scheme irrigators who do not have water use permit and who are located at the tail 
end of the scheme. Whenever some misunderstandings happen, the scheme members in MFIS cut off the supply of water to the UUMGO causing complaints and sometimes active quarrels between them. These conflicts are distributional and relational in nature because they arise not due to inadequate water supplies but due to deliberate decisions by the MFIS group to manipulate the supplies. Generally, although some scholars have found peaceful distribution of the water resources even in the situations of acute scarcity (Bogale and Korf 2007) in Lecoutere (2010), in this study scarcity is a contributing factors for water users conflicts similar to what Lecoutere (2010), Mbeyale (2009), USAID, (2014), Bijani and Hayati, 2015) have found.

\subsubsection{Benefits Accrued}

Benefits accrued from irrigated rice farming have positive association (0.095) with water users' conflicts and is statistically significant at $p<0.001$. These results suggest that an increase in benefits accrued from irrigated rice farming by one unit increases the probability of water conflicts by $9.5 \%$ among the farmers. As it is generally asserted, to most poor people natural resources are highly beneficial because they provide for their survival. In MIS, water is a very crucial resource because it supports the farmers' livelihoods. The household survey has indicated that $84 \%$ of the farmers irrigating in the scheme and $90 \%$ of those irrigating out of the scheme depend on irrigated rice farming as their primary economic activity. This leads to a conclusion that most farmers in the MIS have high dependence on the water and land resources. High dependence on water possibly increased the irrigator's desire to increase his/her share and if necessary prevent others from getting it, thus increasing competition and conflicts with the other users. Such desires have caused the out of scheme farmers in UUMGO to steal water from each other leading to frequent clashes. Furthermore, due to high dependence on water, the desire to access it has increased among the farmers in areas surrounding the MIS leading to high demand and consequently scrambles and conflicts over such resources. Although water is beneficial to both the scheme members and out of scheme irrigators, the desire to increase access and prevent others from getting it is higher in the later than the former due to limited supplies caused by poor irrigation technologies.

\section{Conclusion}

This study aimed to understand water user's conflict in water irrigation scheme and determine types, causes, prevalence, and factors influencing water users' conflict in Mkindo Irrigation Scheme. Results showed that MIS has high magnitude of water users' conflicts despite existence of the statutory control instruments. Adoption of water use permit and tariff systems has resulted to new types of conflicts between the users with permits and those having no permits to use water. Those with water use permits (MFIS members) assume that they have exclusive ownership to the schemes and the water resource. The findings have also shown that there are also intra-group conflicts found amongst the farmers in water users groups found in the scheme.

Although challenges in management of water allocation and users' conflicts have been found across MIS schemes, its severity is higher in areas where there is poor irrigation technology. To enhance water allocation processes in Mkindo Irrigation Scheme, the study recommends 
external facilitation of water allocation process through construction of effective allocation technologies by the government and private stakeholders. This is crucial for evolution of innovative practices in water resource management, and particularly, water allocation processes.

\section{References}

Bijani, M., \& Hayati, D. (2015). Farmers' Perceptions toward Agricultural Water Conflict: The Case of Doroodzan Dam Irrigation Network, Iran. Journal of Agricultural Science and Technology, 17(3), 561-575.

IUCN (2010). Wami Basin Situation Analysis: Report for Wami Ruvu Basin Office

Keraita, B., Mahoo, H., \& Giordano, M. (2012). Impacts of improving traditional irrigation schemes in Mvomero district, Tanzania.

Komakech, H. C., Van der Zaag, P., \& Van Koppen, B. (2012). The Last Will Be First: Water Transfers from Agriculture to Cities in the Pangani River Basin, Tanzania. Water Alternatives, 5(3).

Komakech, H., Van Koppen, B., Mahoo, H., \& Van Der Zaag, P. (2011). Pangani River Basin over time and space: On the interface of local and basin level responses. Agricultural Water Management, 98(11), 1740-1751. https://doi.org/10.1016/j.agwat.2010.06.011

Kramm, J., \& Wirkus, L. (2010). Local Water Governance: Negotiating water access and resolving resource conflicts in Tanzanian irrigation schemes.

Le Quesne, T., Pegram, G., \& Heyden, V. C. (2007). Allocating Scarce Water: A Primer on Water Allocation, Water Rights and Markets. Water Security Series: April 2007

Lecoutere, E. (2010). Institutions under Construction: Resolving Resources Conflict in Tanzanian Irrigation Schemes, MICROCON Research Working Paper 23

Maganga, F. P., Kiwasila, H. L., Juma, I. H., \& Butterworth, J. A. (2004). Implications of customary norms and laws for implementing IWRM: findings from Pangani and Rufiji basins, Tanzania. Physics and chemistry of the Earth, Parts A/B/C, 29(15-18), 1335-1342. https://doi.org/10.1016/j.pce.2004.09.008

Mbeyale, E. G. (2009). Impact of Institutional Changes on Management of Common Pool Resources in Pangani River Basin. A Thesis Submitted in Fulfilment of the Requirement for the Degree of Doctor of Philosophy (Geography) of University of Dar es Salaam

Mdee, A., Harrison, E., Mdee, C., Mdee, E., \& Bahati, E. (2014). The politics of small-scale irrigation in Tanzania: making sense of failed expectations. Working Paper-Future Agricultures, (107).

Meinzen-Dick, R., \& Nkonya, L. (2007). Understanding Legal Pluralism in Water and Land Rights: Lessons from Africa and Asia in van Koppen, B., Giordano M., and Butterworth, J., (eds.) Community-based Water Law and Water Resource Management Reform in Developing Countries, CAB International 


\section{Macrothink}

Journal of Public Administration and Governance ISSN 2161-7104 2018, Vol. 8, No. 4

Mkavidanda, T. A. J., \& Kaswamila, A. L. (2001). The role of traditional irrigation systems (vinyungu) in alleviating poverty in Iringa rural district, Tanzania.

Mutiga, J. K., Mavengano, S. T., Zhongbo, S., Woldai, T., \& Becht, R. (2010). Water allocation as a planning tool to minimise water use conflicts in the Upper Ewaso Ng'iro North Basin, Kenya. Water resources management, 24(14), 3939-3959. https://doi.org/10.1007/s11269-010-9641-9

Ostrom, E. (2000). Private and Common Property Rights: Workshop in Political Theory and Policy Analysis, and Center for the Study of Institutions, Population, and Environmental Change, Indiana University.

United Nations. (2014). Principles and Practices of Water Allocation among Water Use Sectors, Water Resource Series, No. 8 New York, United Nation Publication

United Republic of Tanzania (2002). National Water Policy, Ministry of Water and Livestock Development, Dar es Salaam.

United Republic of Tanzania (2010). National Irrigation Policy (NIP)

United Republic of Tanzania (2016). United Republic of Tanzania (2016), Second Five-Year Development Plan (FYDP II) 2016/2017-2020/2021, Ministry of Finance and Planning, Dar es Salaam.

van Koppen, B., Giordano, M., \& Butterworth, J. (2007). (eds.) Community-based Water Law and Water Resource Management Reform in Developing Countries, CAB International.

van Koppen, B., Sokile, C. S., Hatibu, N., Lankford, B. A., Mahoo, H., \& Yanda, P. Z. (2004). Formal water rights in rural Tanzania: deepening the dichotomy? (Vol. 71). IWMI.

\section{Copyright Disclaimer}

Copyright for this article is retained by the author(s), with first publication rights granted to the journal.

This is an open-access article distributed under the terms and conditions of the Creative Commons Attribution license (http://creativecommons.org/licenses/by/4.0/). 